\title{
VALIDASI PAKET PROGRAM NODAL3 UNTUK KASUS STATIS BENCHMARK TERAS REAKTOR PWR
}

\author{
Tagor Malem Sembiring dan Surian Pinem \\ Pusat Teknologi Reaktor dan Keselamatan Nuklir, BATAN \\ Kawasan PUSPIPTEK Gd. No. 80 Serpong \\ e-mail:tagorms@batan.go.id
}

Diterima 15 Mei 2012, diterima dalam bentuk perbaikan 28 Juni 2012, disetujui 29 Juni 2012

\begin{abstract}
ABSTRAK
VALIDASI PAKET PROGRAM NODAL3 UNTUK KASUS STATIS TERAS BENCHMARK REAKTOR PWR. Persamaan difusi neutron dengan metode nodal telah menjadi metode standar dalam perhitungan parameter neutronik teras reaktor daya air ringan, seperti reaktor air bertekanan (PWR) atau air mendidih (BWR), karena waktu komputasi yang cepat dan hasilnya akurat. Paket program NODAL3 telah dikembangkan untuk menyelesaikan persamaan difusi neutron dengan metode nodal polinom (PNM) dalam geometri 3-dimensi (3-D). Validasi hasil perhitungan NODAL3 untuk kasus statis teras benchmark reaktor PWR (Pressurized Water Reactor), seperti IAEA-2D, BIBLIS, KOEBERG dan IAEA-3D, disajikan dalam penelitian ini. Teras benchmark yang dipilih mewakili kasus 2-D dan 3-D dan mempunyai karaktristik yang berbeda, sehingga dapat menentukan keakuratan NODAL3 dari aspek neutronik yang luas. Parameter neutronik statis yang dihitung adalah faktor perlipatan efektif, keff, faktor puncak daya (FPD) dan profil distribusi FPD ke arah aksial. Dibandingkan dengan acuan, hasil perhitungan NODAL3 menunjukkan bahwa untuk nilai keff terdapat perbedaan maksimum sebesar 0,006\% $(\Delta k)$. Sedangkan untuk FPD radial dan FPD aksial maksimum, selisih maksimum dengan acuan masing-masing sebesar -0,006 dan 0,051. Untuk kasus 3-D, hasil perhitungan NODAL3 konsisten dengan hasil perhitungan paket program nodal tervalidasi PARCS dan NESTLE. Riset ini menunjukkan bahwa akurasi paket program NODAL3 dalam menghitung parameter neutronik teras benchmark reaktor PWR, baik kasus 2-D dan 3-D, menunjukkan hasil yang sangat memuaskan. Oleh karena itu, paket program NODAL3 siap untuk diaplikasikan dalam analisis neutronik reaktor PWR yang riil.
\end{abstract}

Kata kunci : metode nodal, reaktor PWR, teras benchmark, faktor perlipatan efektif, faktor puncak daya

\section{ABSTRACT}

THE VALIDATION OF THE NODAL3 CODE FOR STATIC CASE OF THE PWR BENCHMARK CORES. The neutron diffusion equation with nodal method has become the standard method in the calculation of neutronic parameters of light water power plant reactor, such as pressurized water (PWR) and boiling water (BWR), since the computation is fast and gives the accurate results. The NODAL3 code has been developed to solve the neutron diffusion equation with polynomial nodal methods (PNM) in 3-dimensional (3-D) geometry. The validation of the NODAL3 code for static cases of the PWR benchmark cores, such as IAEA-2D, BIBLIS, KOEBERG and IAEA-3D, are presented in this research work. The selected benchmark cores correspond to the 2-D and 3-D cases and have different characteristics so can determine the accuracy of the NODAL3 code from the broad neutronic aspect. The calculated static neutronic parameters are the effective multiplication factor, keff, the power peaking factor (PPF) and the axial power peaking factor of profile distribution. The NODAL3 calculation results compared to the references shown that the maximum difference of keff was $0.006 \%(\Delta k)$. As for the radial and axial maximum PPF, the maximum difference was -0.006 and 0.051 , respectively. The calculation results of the 3-D cases of NODAL3 are consistent with the calculation results of the validated nodal codes of PARCS and NESTLE. This research shows that the accuracy of the NODAL3 code in the calculation of static neutronic parameters of the PWR benchmark cores, both the 2-D and 3-D cases very satisfactory results. Therefore, the NODAL3 code is ready to be applied in the neutronic analysis of a real PWR reactor.

Key words: nodal method, PWR reactor, benchmark core, effective multiplication factor, power peaking factor

\section{PENDAHULUAN}

Denentuan parameter neutronik dalam kondisi statis untuk reaktor daya air ringan masih relevan untuk dilakukan terutama dalam meningkatkan akurasi hasil perhitungan. Metode perhitungan yang lazim digunakan dalam analisis paremeter neutronik reaktor daya adalah metode nodal karena ukuran perangkat bahan bakar reaktor daya air ringan relatif besar (1). Disamping itu, dengan metode nodal, waktu komputasi yang diperlukan sangat efisien dibanding dengan metode beda hingga (finite difference). Hal ini disebabkan karena metode nodal 
membutuhkan lebih sedikit mesh dibanding metode beda hingga untuk mendapatkan akurasi hasil perhitungan yang relatif sama ${ }^{(1)}$.

Paket program NODAL3 merupakan perangkat analitis untuk perhitungan parameter teras reaktor menggunakan persamaan difusi neutron banyak kelompok dengan metode nodal polinom (polynomial nodal method, PNM) dalam geometri 3-dimensi (2). Akurasi perhitungan program ini telah diuji untuk menentukan boron kritis dalam kasus benchmark NEACRP dengan hasil sangat memuaskan jika dibanding dengan hasil paket program nodal lainnya ${ }^{(3)}$. Namun demikian uji validitas NODAL3 untuk perhitungan parameter neutronik yang statis, seperti faktor perlipatan efektif dan faktor puncak daya ke arah radial dan aksial, belum pernah dilakukan. Oleh karena itu, tujuan dari penelitian ini adalah menentukan akurasi paket program NODAL3 dalam perhitungan kasus statis neutronik untuk teras benchmark reaktor PWR (Pressurized Water Reactor).

Teras benchmark yang dipilih dalam penelitian ini mempertimbangkan variasi geometri, 2-dimensi (2-D) dan 3-dimensi (3-D) dan kedekatan dengan kondisi riil reaktor PWR. Disamping itu, teras benchmark harus memiliki karakteristik untuk dapat mengetahui akurasi numerik dalam menangani jumlah kelompok tenaga neutron dan adanya gangguan fluks neutron yang besar akibat batang kendali. Oleh karena itu, teras benchmark yang dipilih adalah teras IAEA-2D (4), BIBLIS-2D (4), KOEBERG ${ }^{(4)}$ dan IAEA-3D (5). Meskipun teras benchmark tersebut dibuat sudah lama sekali, tahun $1977^{(4,5)}$, akan tetapi sangat luas dipakai dalam menguji validitas suatu metode perhitungan parameter neutronik teras sampai saat ini (6-9). Hal ini yang menjadi alasan untuk menggunakan teras benchmark tersebut dalam penelitian ini. Hasil perhitungan yang memuaskan dari penelitian ini akan menentukan langkah berikutnya dalam aplikasi paket program NODAL3 untuk perhitungan parameter neutronik reaktor daya air ringan yang riil.

\section{METODOLOGI}

Semua perhitungan parameter neutronik teras benchmark PWR kasus 2-dimensi (2-D) dan 3-dimensi (3D) dilakukan dengan paket program NODAL3 (2). Seperti disinggung sebelumnya paket program NODAL3 menggunakan metode difusi neutron 3-D dan banyak kelompok tenaga neutron dengan mengaplikasikan metode Nodal. Program ini dioperasikan di dalam Operating System WINDOWS di Personal Computer (PC) dengan memori 2GB.

\section{Perhitungan Parameter Neutronik Kasus 2-Dimensi Deskripsi teras benchmark 2-D}

Teras benchmark yang dipilih untuk kasus 2-D adalah teras IAEA-2D (4), BIBLIS (4) dan KOEBERG (4). Teras IAEA-2D merupakan teras reaktor air ringan (LWR, light water reactor) yang sangat sederhana dengan model geometri X-Y yang terdiri dari 177 perangkat bahan bakar (fuel assembly, FA) yang homogen dalam 2 (dua) kelompok energi neutron seperti disajikan dalam Gambar 1 dan Tabel $1{ }^{(4)}$. Ukuran pitch setiap FA adalah $20 \mathrm{~cm} \times$ $20 \mathrm{~cm}$.

\begin{tabular}{|c|c|c|c|c|c|c|c|c|}
\hline 3 & 2 & 2 & 2 & 3 & 2 & 2 & 1 & 4 \\
\hline 2 & 2 & 2 & 2 & 2 & 2 & 2 & 1 & 4 \\
\hline 2 & 2 & 2 & 2 & 2 & 2 & 1 & 1 & 4 \\
\hline 2 & 2 & 2 & 2 & 2 & 2 & 1 & 4 & 4 \\
\hline 3 & 2 & 2 & 2 & 3 & 1 & 1 & 4 & \\
\hline 2 & 2 & 2 & 2 & 1 & 1 & 4 & 4 & \\
\hline 2 & 2 & 1 & 1 & 1 & 4 & 4 & & \\
\hline 1 & 1 & 1 & 4 & 4 & 4 & & & \\
\hline 4 & 4 & 4 & 4 & & & & & \\
\hline
\end{tabular}

Gambar 1. Konfigurasi teras IAEA-2D (4)

Teras IAEA-2D disusun atas 3 (tiga) jenis FA yang diwakili oleh 3 (tiga) zona, yaitu:

1. Zona 1, merupakan FA jenis ke-1,

2. Zona 2, merupakan $F A$ jenis ke-2 dan

3. Zona 3, merupakan FA jenis ke-3 yang merupakan homogenisasi antara bahan bakar dan penyerap. 
Zona 4 merupakan daerah reflektor $\mathrm{H}_{2} \mathrm{O}$. Keunikan teras benchmark ini adalah dapat menguji akurasi paket program perhitungan teras dalam menangani adanya ganguan (perturbation) yang besar di teras akibat adanya serapan neutron termal yang besar di Zona $3{ }^{(4)}$.

Tabel 1. Data tampang lintang teras IAEA-2D (4)

\begin{tabular}{|c|c|c|c|c|c|}
\hline Zone & Kelompok & $D_{\mathrm{g}}, \mathrm{cm}$ & \multicolumn{1}{|c|}{$\Sigma_{\mathrm{ag}}, \mathrm{cm}^{-1}$} & $\mathrm{v} \Sigma_{\mathrm{fg}}, \mathrm{cm}^{-1}$ & $\Sigma_{\mathrm{sg} 1, \mathrm{~cm}^{-1}}$ \\
\hline 1 & 1 & 1,5 & 0,010120 & 0,000 & 0,000 \\
& 2 & 0,4 & 0,080032 & 0,135 & 0,020 \\
2 & 1 & 1,5 & 0,010120 & 0,000 & 0,000 \\
3 & 2 & 0,4 & 0,085032 & 0,135 & 0,020 \\
& 1 & 1,5 & 0,010120 & 0,000 & 0,000 \\
4 & 2 & 0,4 & 0,130032 & 0,135 & 0,200 \\
& 1 & 2,0 & 0,000160 & 0,000 & 0,000 \\
& 2 & 0,3 & 0,010024 & 0,000 & 0,040 \\
\hline
\end{tabular}

Kasus BIBLIS-2D adalah persoalan 2-D yang realistis dan higly nonseparable 2-group, sehingga mewakili operasi aktual reaktor PWR dangan checker-board-loaded core (4). Seperti terlihat di Gambar 2, teras dibagi atas 7 (tujuh) jenis FA yang homogen dan masing-masing memiliki komposisi berbeda (Zona 1, 2, 4, 5,6, 7 dan 8) dengan dimensi sebesar 23,1226 cm $\times 23,1226 \mathrm{~cm}$. Perangkat bahan bakar dikelilingi oleh reflektor $\mathrm{H}_{2} \mathrm{O}$ (Zona 3) dengan dimensi yang sama. Data tampang lintang penyusun teras BIBLIS-2D disajikan pada Tabel 2.

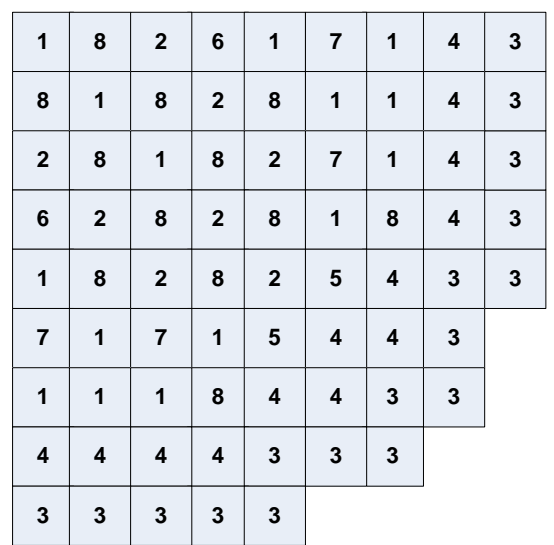

Gambar 2. Konfigurasi teras BIBLIS-2D (4)

Tabel 2. Data tampang lintang teras BIBLIS-2D (4)

\begin{tabular}{|c|c|c|c|l|l|}
\hline Zone & Kelompok & $D_{\mathrm{g}, \mathrm{cm}}$ & \multicolumn{1}{|c|}{$\sum_{\mathrm{ag}, \mathrm{cm}^{-1}}$} & \multicolumn{1}{|c|}{$\mathrm{v} \Sigma_{\mathrm{fg}}, \mathrm{cm}^{-1}$} & \multicolumn{1}{|c|}{$\sum_{\mathrm{sg} 1} \mathrm{~cm}^{-1}$} \\
\hline 1 & 1 & 1,4360 & 0,0095042 & 0,0058708 & 0,000 \\
& 2 & 0,3635 & 0,075058 & 0,0960670 & 0,017754 \\
2 & 1 & 1,4366 & 0,0096785 & 0,0061908 & 0,000 \\
& 2 & 0,3636 & 0,0784360 & 0,1035800 & 0,017621 \\
3 & 1 & 1,3200 & 0,0026562 & 0,000 & 0,000 \\
& 2 & 1,4389 & 0,0715960 & 0,000 & 0,023106 \\
4 & 1 & 1,4389 & 0,0103630 & 0,0074527 & 0,000 \\
& 2 & 0,3638 & 0,0914080 & 0,1323600 & 0,017101 \\
5 & 1 & 1,4381 & 0,0100030 & 0,0061980 & 0,000 \\
& 2 & 0,3665 & 0,0848280 & 0,1035800 & 0,017290 \\
6 & 1 & 1,4385 & 0,0101320 & 0,0064285 & 0,000 \\
& 2 & 0,3665 & 0,0873140 & 0,1091100 & 0,017192 \\
7 & 1 & 1,4389 & 0,0101650 & 0,0061908 & 0,000 \\
& 2 & 0,3679 & 0,0880240 & 0,1035800 & 0,017125 \\
8 & 1 & 1,4393 & 0,0102940 & 0,0064285 & 0,000 \\
& 2 & 0,3680 & 0,0905100 & 0,1091100 & 0,017027 \\
\hline
\end{tabular}


Teras benchmark KOEBERG ini diperuntukkan untuk menguji akurasi suatu paket program dalam menangani tampang lintang makroskopis hamburan neutron. Oleh karena itu data tampang lintang neutronnya sebanyak 4 (empat) kelompok tenaga neutron. Teras benchmark ini diadopsi dari teras reaktor PWR Koeberg Unit 1 pada awal siklus, sehingga merupakan kondisi yang riil (4). Seperti ditunjukkan dalam Gambar 3, teras KOEBERG terdiri dari 157 perangkat bahan bakar yang homogen yang terdiri dari 3 (tiga) jenis pengkayaan dan 3 (tiga) jenis pemuatan penyerap yang dinyatakan oleh Zona 1-6. Sedangkan Zona 7 merupakan homogenisasi reflektor $\left(\mathrm{H}_{2} \mathrm{O}+\right.$ boron $)$ dengan baffle. Tiap perangkat berukuran $21,608 \mathrm{~cm} \times 21,608 \mathrm{~cm}$. Data tampang lintang tiap zona dalam 4 (empat) kelompok tenaga neutron ditunjukkan di Tabel 3.

\begin{tabular}{|c|c|c|c|c|c|c|c|c|}
\hline 1 & 3 & 1 & 3 & 1 & 2 & 1 & 4 & 7 \\
\hline 3 & 1 & 3 & 1 & 2 & 1 & 6 & 4 & 7 \\
\hline 1 & 3 & 1 & 2 & 1 & 3 & 4 & 7 & 7 \\
\hline 3 & 1 & 2 & 1 & 3 & 5 & 4 & 7 & \\
\hline 1 & 2 & 1 & 3 & 1 & 4 & 7 & 7 & \\
\hline 2 & 1 & 3 & 5 & 4 & 7 & 7 & & \\
\hline 1 & 6 & 4 & 4 & 7 & 7 & & & \\
\hline 4 & 4 & 7 & 7 & 7 & & & & \\
\hline 7 & 7 & 7 & & & & & & \\
\hline
\end{tabular}

Gambar 3. Konfigurasi teras KOEBERG (4)

Tabel 3. Data tampang lintang untuk teras KOEBERG (4)

\begin{tabular}{|c|c|c|c|c|c|c|c|c|}
\hline Zone & Kelom-pok & $D_{g}, \quad \mathrm{~cm}$ & $\Sigma_{\mathrm{ag}, \mathrm{cm}^{-1}}$ & $v \Sigma_{\mathrm{fg}}, \mathrm{cm}^{-1}$ & $\Sigma_{\mathrm{sg} 1}, \mathrm{~cm}^{-1}$ & $\Sigma_{\mathrm{sg} 2}, \mathrm{~cm}^{-1}$ & $\Sigma_{\mathrm{sg} 3}, \quad \mathrm{~cm}^{-1}$ & $\sum_{\mathrm{sg} 4}, \mathrm{~cm}^{-1}$ \\
\hline \multirow[t]{4}{*}{1} & 1 & 2,491869 & 0,003654 & 0,008228 & 0,000 & 0,000 & 0,000 & 0,000 \\
\hline & 2 & 1,045224 & 0,002124 & 0,000536 & 0,063789 & 0,000 & 0,000 & 0,000 \\
\hline & 3 & 0,677407 & 0,019908 & 0,007058 & 0,000486 & 0,064381 & 0,000 & 0,001245 \\
\hline & 4 & 0,375191 & 0,067990 & 0,083930 & 0,000 & 0,000003 & 0,050849 & 0,000 \\
\hline \multirow[t]{4}{*}{2} & 1 & 2,492653 & 0,003685 & 0,008295 & 0,000 & 0,000 & 0,000 & 0,000 \\
\hline & 2 & 1,049844 & 0,002215 & 0,000713 & 0,063112 & 0,000 & 0,000 & 0,000 \\
\hline & 3 & 0,676610 & 0,022012 & 0,009230 & 0,000478 & 0,063078 & 0,000 & 0,001543 \\
\hline & 4 & 0,379451 & 0,085052 & 0,108244 & 0,000 & 0,000003 & 0,048420 & 0,000 \\
\hline \multirow[t]{4}{*}{3} & 1 & 2,491978 & 0,003684 & 0,008459 & 0,000 & 0,000 & 0,000 & 0,000 \\
\hline & 2 & 1,051910 & 0,002221 & 0,000713 & 0,062765 & 0,000 & 0,000 & 0,000 \\
\hline & 3 & 0,677084 & 0,022403 & 0,009214 & 0,000473 & 0,062404 & 0,000 & 0,001598 \\
\hline & 4 & 0,381453 & 0,088077 & 0,108087 & 0,000 & 0,000003 & 0,047549 & 0,000 \\
\hline \multirow[t]{4}{*}{4} & 1 & 2,4925351 & 0,003740 & 0,008409 & 0,000 & 0,000 & 0,000 & 0,000 \\
\hline & 2 & 045298 & 0,002299 & 0,000923 & 0,063737 & 0,000 & 0,000 & 0,000 \\
\hline & 3 & 0,674684 & 0,022621 & 0,011714 & 0,000486 & 0,064330 & 0,000 & 0,001630 \\
\hline & 4 & 0,374240 & 0,091000 & 0,133600 & 0,000 & 0,000003 & 0,049518 & 0,000 \\
\hline \multirow[t]{4}{*}{5} & 1 & 2,492329 & 0,003730 & 0,008409 & 0,000 & 0,000 & 0,000 & 0,000 \\
\hline & 2 & 1,051953 & 0,002315 & 0,000921 & 0,062737 & 0,000 & 0,000 & 0,000 \\
\hline & 3 & 0,675683 & 0,023822 & 0,011675 & 0,000473 & 0,062376 & 0,000 & 0,001797 \\
\hline & 4 & 0,380606 & 0,100246 & 0,134282 & 0,000 & 0,000003 & 0,046859 & 0,000 \\
\hline \multirow[t]{4}{*}{6} & 1 & 2,491521 & 0,003740 & 0,008400 & 0,000 & 0,000 & 0,000 & 0,000 \\
\hline & 2 & 1,055029 & 0,002321 & 0,000921 & 0,062386 & 0,000 & 0,000 & 0,000 \\
\hline & 3 & 0,676197 & 0,024196 & 0,011651 & 0,000468 & 0,061696 & 0,000 & 0,001852 \\
\hline & 4 & 0,382434 & 0,103283 & 0,133974 & 0,000 & 0,000003 & 0,046005 & 0,000 \\
\hline \multirow[t]{4}{*}{7} & 1 & 2,119737 & 0,000466 & 0,000 & 0,000 & 0,000 & 0,000 & 0,000 \\
\hline & 2 & 0,980098 & 0,000263 & 0,000 & 0,042052 & 0,000 & 0,000 & 0,000 \\
\hline & 3 & 0,531336 & 0,004282 & 0,000 & 0,000322 & 0,044589 & 0,000 & 0,000978 \\
\hline & 4 & 1,058029 & 0,116918 & 0,000 & 0,000 & 0,000 & 0,052246 & 0,000 \\
\hline
\end{tabular}




\section{Penyelesaian kasus -2D}

Parameter neutronik kasus statis yang dihitung dalam teras benchmark untuk kasus 2-D adalah:

- faktor perlipatan efektif, $k_{\text {eff, }}$ yang merupakan parameter global teras akibat populasi neutron di seluruh teras.

- distribusi faktor puncak daya radial (radial power peaking factor), $\mathrm{FPD}_{\mathrm{R}}$, merupakan parameter teras yang menunjukkan kerataan pembangkitan panas yang merupakan efek dari perbedaan pembangkitan panas di suatu perangkat bahan bakar dibanding dengan pembangkitan panas rerata seluruh teras ke arah radial.

Dalam kasus 2-D, efek jumlah node di setiap perangkat perangkat divariasi dalam menentukan parameter teras dilakukan, yaitu:

1. Penggunaan node $1 \times 1$ untuk setiap perangkat,

2. Penggunaan node $2 \times 2$ untuk setiap perangkat.

Karena dalam kasus ini, seluruh teras benchmark dalam bentuk $1 / 4$-teras simetris, maka syarat batas ke arah depan dan samping kiri adalah reflective, $\left(\frac{\partial \emptyset\left(\bar{r}^{-}\right)}{\partial \bar{r}^{-}}=\frac{\partial \emptyset\left(\bar{r}^{+}\right)}{\partial \bar{r}^{+}}\right)$dan syarat batas ke arah belakang dan kanan adalah vacuum, $\left(\frac{\partial \emptyset(\bar{r})}{\partial \bar{r}}=0\right)$. Nilai konvergensi untuk $k_{\text {eff }}$ dan fluks neutron adalah $1 \times 10^{-5}$.

\section{Perhitungan Parameter Neutronik Kasus 3-Dimensi Deskripsi teras benchmark 3-D}

Dalam penelitian ini, kasus 3-D yang dipilih hanya satu teras yaitu teras benchmark IAEA-3D (5). Teras IAEA-3D mewakili teras PWR dengan data tampang lintang yang tipikal untuk 177 perangkat bahan bakar, termasuk 9 perangkat batang kendalinya yang masuk penuh (fully inserted) dan 4 perangkat batang kendali yang masuk sebagian (partially inserted). Seperti ditunjukkan Gambar 4 dan 5, ukuran tiap perangkat bahan bakar 20 $\mathrm{cm} \times 20 \mathrm{~cm}$ dengan tinggi aktif $340 \mathrm{~cm}$. Tinggi reflektor air $\left(\mathrm{H}_{2} \mathrm{O}\right)$ untuk daerah di atas dan di bawah teras aktif masing-masing $20 \mathrm{~cm}$. Teras IAEA-3D terdiri dari 3 (tiga) zona perangkat bahan bakar, yaitu:

1. Zona 1 adalah FA jenis pertama (Fuel 1 ),

2. Zona 2 adalah FA jenis pertama dan batang kendali (Fuel $1+$ Absorber), dan

3. Zona 3 adalah FA jenis kedua (Fuel 2).

Zona 4 adalah reflektor $\mathrm{H}_{2} \mathrm{O}$ dan Zona 5 adalah daerah homogenisasi reflektor dan batang kendali.

Tabel 5 menyajikan data tampang lintang 2-kelompok tiap zona penyusun teras IAEA-3D.

\begin{tabular}{|c|c|c|c|c|c|c|c|c|}
\hline 2 & 1 & 1 & 1 & 2 & 1 & 1 & 3 & 4 \\
\hline 1 & 1 & 1 & 1 & 1 & 1 & 1 & 3 & 4 \\
\hline 1 & 1 & 2 & 1 & 1 & 1 & 3 & 3 & 4 \\
\hline 1 & 1 & 1 & 1 & 1 & 1 & 3 & 4 & 4 \\
\hline 2 & 1 & 1 & 1 & 2 & 3 & 3 & 4 & \\
\hline 1 & 1 & 1 & 1 & 3 & 3 & 4 & 4 & \\
\hline 1 & 1 & 3 & 3 & 3 & 4 & 4 & & \\
\hline 3 & 3 & 3 & 4 & 4 & 4 & & & \\
\hline 4 & 4 & 4 & 4 & 4 & & & & \\
\hline
\end{tabular}

Gambar 4. Konfigurasi radial teras IAEA-3D (5) 


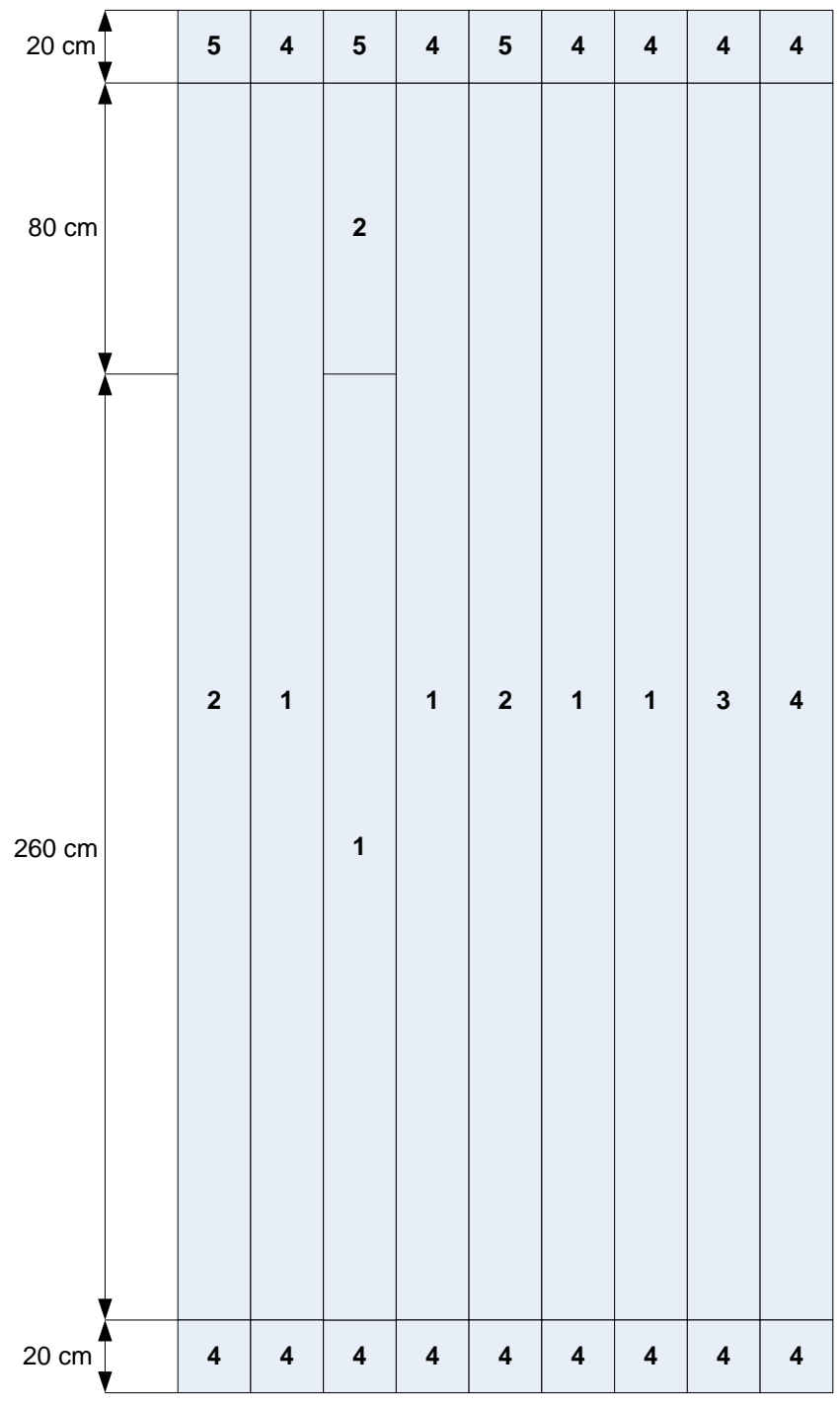

Gambar 5. Konfigurasi aksial teras IAEA-3D (5)

Tabel 4. Data tampang lintang teras IAEA-3D (5)

\begin{tabular}{|c|c|c|c|c|c|c|}
\hline Zona & Material & Kelompok & $D_{g}, \mathrm{~cm}$ & $\Sigma_{\mathrm{ag}, \mathrm{Cm}^{-1}}$ & $v \Sigma_{\mathrm{fg}}, \mathrm{cm}^{-1}$ & $\Sigma_{\mathrm{sg} 1}, \mathrm{~cm}^{-1}$ \\
\hline \multirow[t]{2}{*}{1} & Fuel 1 & 1 & 1,5 & 0,01 & 0,000 & 0,000 \\
\hline & & 2 & 0,4 & 0,085 & 0,135 & 0,020 \\
\hline \multirow[t]{2}{*}{2} & Fuel $1+$ Absorber & 1 & 1,5 & 0,01 & 0,000 & 0,000 \\
\hline & & 2 & 0,4 & 0,13 & 0,135 & 0,020 \\
\hline \multirow[t]{2}{*}{3} & Fuel 2 & 1 & 1,5 & 0,01 & 0,000 & 0,000 \\
\hline & & 2 & 0,4 & 0,08 & 0,135 & 0,200 \\
\hline \multirow[t]{2}{*}{4} & Reflektor & 1 & 2,0 & 0,000 & 0,000 & 0,000 \\
\hline & & 2 & 0,3 & 0,01 & 0,000 & 0,040 \\
\hline \multirow[t]{2}{*}{5} & Reflektor + & 1 & 2,0 & 0,000 & 0,000 & 0,000 \\
\hline & Absorber & 2 & 0,3 & 0,055 & 0,000 & 0,040 \\
\hline
\end{tabular}

\section{Penyelesaian kasus -3D}

Dalam kasus 3-D dengan teras IAEA-3D, seluruh syarat batas dan pembagian node ke arah radial sama dengan kasus 2-D. Sedangkan untuk ke arah aksial, daerah aktif dengan tinggi $340 \mathrm{~cm}$, dibagi dalam 17 nodes dengan ukuran $20 \mathrm{~cm}$. Dalam kasus 3-D, parameter teras yang dihitung adalah $k_{\text {eff, }}$ distribusi $F P D_{R}$, nilai FPD maksimum ke arah aksial $\left(\mathrm{FPD}_{\mathrm{Amax}}\right)$ dan distribusi FPD ke arah aksial di posisi terjadinya $\mathrm{FPD}_{\mathrm{Amax}}$. 
Akurasi hasil perhitungan paket program NODAL3 dibandingkan dengan nilai acuan (reference values) untuk

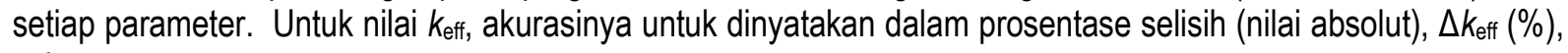
yaitu:

$$
\Delta k_{\text {eff }}(\%)=\left|k_{\text {eff }}^{a c u a n}-k_{\text {eff }}^{N O D A L 3}\right| \times 100 \%
$$

dengan:

$k_{\text {eff }}^{\text {acuan }}=$ nilai $k_{\text {eff }}$ acuan

$k_{\mathrm{eff}}^{N O D A L 3}=$ nilai $k_{\text {eff }}$ hasil perhitungan NODAL3

Sedangkan untuk nilai FPD, akurasi dinyatakan dalam selisih nilai acuan dan perhitungan NODAL-3, sehingga nilainya dapat bernilai positif dan negatif untuk menunjukkan nilai yang lebih tinggi atau lebih rendah dibanding FPD acuan. Dalam penelitian ini juga dilakukan validasi distribusi $F P D_{R}$ untuk tiap perangkat bahan bakar di teras benchmark. Parameter ini penting karena menunjukkan karakteristik distribusi pembangkitan panas di teras. Untuk itu, validitas distribusi $F P_{R}$ di teras hasil perhitungan dengan acuan dinyatakan dalam root mean square (RMS), yaitu:

$$
\mathrm{RMS}=\sqrt{\frac{\sum_{n=1}^{N}\left(F P D_{\text {Racuan }, n}-F P D_{\mathrm{RNODAL}} 3, n\right)^{2}}{N}}
$$

dengan,

$$
\begin{array}{ll}
F P D_{\text {Racuan }, n} & =F P D_{R} \text { acuan untuk posisi- } n \\
F P D_{\text {RNODAL } 3, n} & =F P D_{R} \text { hasil perhitungan NODAL-3 untuk posisi-n } \\
N & =\text { jumlah seluruh perangkat bahan bakar di teras }
\end{array}
$$

\section{HASIL DAN PEMBAHASAN}

\section{Kasus 2-Dimensi}

Hasil perhitungan paket program NODAL3 menghitung nilai $k_{\text {eff }}$ teras untuk kasus 2-D disajikan dalam Tabel 5. Terlihat bahwa selisih maksimum hasil perhitungan NODAL3 dengan acuan untuk jumlah node $1 \times 1$ di setiap FA adalah $0,044 \%$. Selisih maksimum ini akan berkurang menjadi $0,006 \%$ jika jumlah node dinaikkan menjadi $2 \times$ 2 di setiap FA untuk semua teras. Hal ini menunjukkan bahwa dengan menaikkan jumlah node di setiap FA, dari 1 $\times 1$ ke $2 \times 2$, akan dapat menaikkan akurasi perhitungan sampai 88,9\% (BIBLIS-2D). Sedangkan untuk teras KOEBERG, peningkatan akurasi sebesar $88,6 \%$ dan teras IAEA-2D sebesar $57 \%$.

Peningkatan akurasi yang rendah di teras IAEA-2D dibanding teras lainnya karena adanya gangguan fluks neutron yang besar akibat adanya serapan neutron di daerah batang kendali (Zona 3). Dengan demikian, jumlah node $2 \times 2$ (di setiap FA) tidak dapat menangani dengan maksimal gradien fluks neutron yang besar di batas antar node. Walaupun tidak menjadi pembahasan dalam riset ini, penambahan jumlah node yang lebih dari $2 \times 2$ harus dilakukan agar mendapatkan akurasi yang tinggi untuk teras yang memiliki karakteristik yang sama dengan teras IAEA-2D. Akan tetapi perlu dicatat, ukuran node yang terlalu kecil dapat mengakibatkan ketidakmampuan metode nodal dalam menyelesaikan eigenvalue problem seperti $k_{\text {eff. }}$ Sehingga penggunaan jumlah node yang optimal

\begin{tabular}{|c|c|c|c|c|c|}
\hline \multirow{2}{*}{$\begin{array}{c}\text { Teras benchmark } \\
\text { 2-D }\end{array}$} & \multirow{2}{*}{ Pitch, cm } & \multicolumn{2}{|c|}{ Program NODAL3 } & \multirow{2}{*}{$k_{\text {eff }}$ acuan (4) } & \multirow{2}{*}{$\begin{array}{c}\text { Perbedaan }^{*} \\
\left(\Delta k_{\text {eff }}(\%)\right)\end{array}$} \\
\hline & & Node & $k_{\text {eff }}$ & & \\
\hline \multirow{2}{*}{ IAEA-2D } & \multirow{2}{*}{20} & $1 \times 1$ & 1,029441 & \multirow{2}{*}{1,029585} & 0,014 \\
\hline & & $2 \times 2$ & 1,029528 & & 0,006 \\
\hline \multirow{2}{*}{ BIBLIS-2D } & \multirow{2}{*}{23,1226} & $1 \times 1$ & 1,025202 & \multirow{2}{*}{1,025110} & 0,009 \\
\hline & & $2 \times 2$ & 1,025095 & & 0,001 \\
\hline \multirow{2}{*}{ KOEBERG } & \multirow{2}{*}{21,608} & $1 \times 1$ & 1,008392 & \multirow{2}{*}{1,007954} & 0,044 \\
\hline & & $2 \times 2$ & 1,008002 & & 0,005 \\
\hline
\end{tabular}
akan menjadi pembatas tingkat akurasi metode nodal untuk teras yang memiliki ganguan fluks neutron yang tinggi. Meskipun demikian, hasil perbedaan $\Delta k_{\text {eff }}(\%)$ sebesar 0,006 di teras IAEA-2D adalah sangat memuaskan, karena perbedaan tersebut jauh lebih kecil dibanding nilai fraksi neutron kasip ( $\left.\beta_{\text {eff }}\right)$ PWR yang bernilai 0,7 .

Tabel 5. Nilai $k_{\text {eff }}$ teras benchmark 2-D hasil perhitungan NODAL3

Catatan : * nilai absolut 
Tabel 6 menunjukkan pengaruh jumlah node terhadap akurasi perhitungan $F P D_{R}$ maksimum $\left(F P D_{R \max }\right)$ Seperti halnya nilai $k_{\text {eff, }}$ akurasi perhitungan $\mathrm{FPD}_{\mathrm{Rmax}}$ sangat bergantung pada jumlah node di tiap $\mathrm{FA}$, yaitu semakin banyak jumlah node, semakin tinggi akurasinya. Dalam penelitian ini ditunjukkan perbedaan maksimum dengan acuan adalah 0,006 untuk jumlah node $2 \times 2$ di tiap FA, yang akurasinya meningkat $62 \%$ dibanding perhitungan dengan jumlah node $1 \times 1$ di tiap FA dengan perbedaan maksimum sebesar -0,016.

Tabel 6. Nilai $F P D_{R}$ maksimum ( $F P D_{R \max }$ ) dan RMS untuk teras benchmark 2-D

\begin{tabular}{|c|c|c|c|c|c|}
\hline \multirow{2}{*}{$\begin{array}{l}\text { Teras 2-D } \\
\text { Benchmark }\end{array}$} & \multicolumn{2}{|c|}{ Program NODAL3 } & \multirow{2}{*}{$\begin{array}{l}\mathrm{FPD}_{\mathrm{Rmax}} \\
\text { Acuan }^{(4)}\end{array}$} & \multirow{2}{*}{$\begin{array}{l}\text { Perbedaan FPD } \mathrm{R}_{\max } \\
\text { (Acuan - NODAL3) }\end{array}$} & \multirow{2}{*}{$\begin{array}{l}\text { RMS (root mean } \\
\text { square) }\end{array}$} \\
\hline & Node & $F P D_{\text {Rmax }}$ & & & \\
\hline \multirow{2}{*}{ IAEA-2D } & $1 \times 1$ & 1,496 & \multirow{2}{*}{1,480} & $-0,016$ & $1,0654 \times 10^{-2}$ \\
\hline & $2 \times 2$ & 1,486 & & 0,006 & $4,1997 \times 10^{-3}$ \\
\hline \multirow{2}{*}{ BIBLIS-2D } & $1 \times 1$ & 1,245 & \multirow{2}{*}{1,243} & $-0,002$ & $5,2859 \times 10^{-3}$ \\
\hline & $2 \times 2$ & 1,245 & & $-0,002$ & $1,7652 \times 10^{-3}$ \\
\hline \multirow{2}{*}{ KOEBERG } & $1 \times 1$ & 1,233 & \multirow{2}{*}{1,243} & 0,010 & $1,3451 \times 10^{-2}$ \\
\hline & $2 \times 2$ & 1,242 & & 0,001 & $1,2453 \times 10^{-3}$ \\
\hline
\end{tabular}

\begin{tabular}{|c|c|c|c|c|c|c|c|}
\hline 0,746 & 1,310 & 1,454 & 1,211 & 0,610 & 0,935 & 0,934 & 0,755 \\
\hline 0,755 & 1,324 & 1,467 & 1,223 & 0,611 & 0,936 & 0,925 & 0,738 \\
\hline$-0,009$ & $-0,014$ & $-0,013$ & $-0,012$ & $-0,001$ & $-0,001$ & 0,009 & 0,017 \\
\hline 1,310 & 1,435 & 1,480 & 1,315 & 1,070 & 1,036 & 0,950 & 0,736 \\
\hline 1,324 & 1,450 & 1,496 & 1,327 & 1,077 & 1,035 & 0,941 & 0,718 \\
\hline$-0,014$ & $-0,015$ & $-0,016$ & $-0,012$ & $-0,007$ & 0,001 & 0,009 & 0,018 \\
\hline 1,454 & 1,480 & 1,469 & 1,345 & 1,179 & 1,071 & 0,975 & 0,692 \\
\hline 1,467 & 1,496 & 1,484 & 1,357 & 1,186 & 1,069 & 0,964 & 0,676 \\
\hline$-0,013$ & $-0,016$ & $-0,015$ & $-0,012$ & $-0,007$ & 0,002 & 0,011 & 0,016 \\
\hline 1,211 & 1,315 & 1,345 & 1,193 & 0,967 & 0,906 & 0,846 & \\
\hline 1,223 & 1,327 & 1,357 & 1,202 & 0,973 & 0,903 & 0,835 & \\
\hline$-0,012$ & $-0,012$ & $-0,012$ & $-0,009$ & $-0,006$ & 0,003 & 0,011 & \\
\hline 0,610 & 1,070 & 1,179 & 0,967 & 0,471 & 0,686 & 0,597 & \\
\hline 0,611 & 1,077 & 1,186 & 0,973 & 0,467 & 0,682 & 0,590 & \\
\hline$-0,001$ & $-0,007$ & $-0,007$ & $-0,006$ & 0,004 & 0,004 & 0,007 & \\
\hline 0,935 & 1,036 & 1,071 & 0,906 & 0,686 & 0,585 & & \\
\hline 0,936 & 1,035 & 1,069 & 0,903 & 0,682 & 0,574 & & \\
\hline$-0,001$ & 0,001 & 0,002 & 0,003 & 0,004 & 0,011 & & \\
\hline 0,934 & 0,950 & 0,975 & 0,846 & 0,597 & & & \\
\hline 0,925 & 0,941 & 0,964 & 0,835 & 0,590 & & & \\
\hline 0,009 & 0,009 & 0,011 & 0,011 & 0,007 & & & \\
\hline 0,755 & 0,736 & 0,692 & & & & & \\
\hline 0,738 & 0,718 & 0,676 & & & & 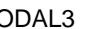 & \\
\hline 0,016 & 0,017 & 0,016 & & & & rbedaa & \\
\hline
\end{tabular}

Gambar 6. Distribusi FPD $R$ teras IAEA-2D hasil NODAL3 dengan jumlah node $1 \times 1$ di setiap FA dibanding dengan nilai acuan ${ }^{(4)}$

\begin{tabular}{|c|c|c|c|c|c|c|c|}
\hline 0,746 & 1,310 & 1,454 & 1,211 & 0,610 & 0,935 & 0,934 & 0,755 \\
\hline 0,748 & 1,316 & 1,460 & 1,215 & 0,611 & 0,934 & 0,931 & 0,746 \\
\hline$-0,002$ & $-0,006$ & $-0,006$ & $-0,004$ & $-0,001$ & $-0,001$ & 0,003 & 0,009 \\
\hline 1,310 & 1,435 & 1,480 & 1,315 & 1,070 & 1,036 & 0,950 & 0,736 \\
\hline 1,316 & 1,442 & 1,486 & 1,319 & 1,072 & 1,036 & 0,947 & 0,728 \\
\hline$-0,006$ & $-0,007$ & $-0,006$ & $-0,004$ & $-0,002$ & 0,000 & 0,003 & 0,008 \\
\hline 1,454 & 1,480 & 1,469 & 1,345 & 1,179 & 1,071 & 0,975 & 0,692 \\
\hline 1,460 & 1,486 & 1,475 & 1,349 & 1,181 & 1,070 & 0,972 & 0,686 \\
\hline$-0,006$ & $-0,006$ & $-0,006$ & $-0,004$ & $-0,002$ & 0,001 & 0,013 & 0,006 \\
\hline 1,211 & 1,315 & 1,345 & 1,193 & 0,967 & 0,906 & 0,846 & \\
\hline 1,215 & 1,319 & 1,349 & 1,196 & 0,968 & 0,906 & 0,843 & \\
\hline$-0,004$ & $-0,004$ & $-0,004$ & $-0,003$ & $-0,001$ & 0,000 & 0,003 & \\
\hline 0,610 & 1,070 & 1,179 & 0,967 & 0,471 & 0,686 & 0,597 & \\
\hline 0,611 & 1,072 & 1,181 & 0,968 & 0,470 & 0,685 & 0,594 & \\
\hline$-0,001$ & $-0,002$ & $-0,002$ & $-0,001$ & 0,001 & 0,001 & 0,003 & \\
\hline 0,935 & 1,036 & 1,071 & 0,906 & 0,686 & 0,585 & & \\
\hline 0,934 & 1,036 & 1,070 & 0,906 & 0,685 & 0,583 & & \\
\hline 0,001 & 0,000 & 0,001 & 0,000 & 0,001 & 0,002 & & \\
\hline 0,934 & 0,950 & 0,975 & 0,846 & 0,597 & & & \\
\hline 0,931 & 0,947 & 0,972 & 0,843 & 0,594 & & & \\
\hline 0,003 & 0,003 & 0,003 & 0,003 & 0,003 & & & \\
\hline 0,755 & 0,736 & 0,692 & & & & & \\
\hline 0,746 & 0,728 & 0,686 & & & & DAL & \\
\hline 0,009 & 0,008 & 0,006 & & & & rbedaa & \\
\hline
\end{tabular}

Gambar 7. Distribusi FPD teras IAEA-2D hasil NODAL3 dengan jumlah node $2 \times 2$ di setiap FA dibanding dengan nilai acuan (4) 
Validitas NODAL3 menghitung distribusi $\mathrm{FPD}_{\mathrm{R}}$ dibanding acuan dapat dilihat di Tabel 6 dalam nilai RMS. Tampak jelas untuk seluruh teras, bahwa dengan ditingkatkannya jumlah node di setiap FA, maka nilai RMS semakin kecil. Hal ini dapat dilihat di Gambar 6 dan 7, untuk teras IAEA-2D, bahwa dengan ditingkatkannya jumlah node maka selisih hasil perhitungan $F P D_{R}$ dan acuan semakin kecil untuk tiap posisi FA. Semakin kecil nilai RMS, menunjukkan bahwa selisih hasil perhitungan dan acuan semakin kecil, yang menunjukkan akurasi perhitungan distribusi $F P D_{R}$ di tiap FA dibanding acuan. Dengan demikian, peningkatan jumlah node memberi dampak semakin meningkatnya akurasi NODAL3 dalam perhitungan distribusi daya $\mathrm{FPD}_{R}$.

Tampak jelas di Tabel 6, bahwa RMS yang paling besar terjadi di teras IAEA-2D dan KOEBERG. Hal ini menunjukkan bahwa dengan adanya gangguan fluks neutron di teras akibat adanya serapan neutron yang besar di teras (IAEA-2D) atau pengaruh tampang lintang hamburan (KOEBERG), mempengaruhi hasil perhitungan distribusi $F P D_{R}$, sehingga untuk teras yang memiliki karakteristik seperti ini, penggunaan jumlah node minimal $2 \times 2$ di tiap FA harus menjadi syarat untuk mendapatkan akurasi yang tinggi.

\section{Kasus 3-Dimensi}

Tabel 7 menunjukkan hasil perhitungan $k_{\text {eff }}$ untuk kasus benchmark 3-dimensi (3-D), teras IAEA-3D, baik itu untuk jumlah node $1 \times 1$ dan $2 \times 2$ di setiap FA. Seperti halnya kasus 2-D, dalam kasus 3-D, peningkatan jumlah node dari $1 \times 1$ dan $2 \times 2$ di setiap FA, juga menaikkan akurasi perhitungan $k_{\text {eff }}$ sebesar $67 \%$, karena $\Delta k_{\text {eff }}$ turun dari $0,012 \%$ menjadi $0,004 \%$. Jika dibanding dengan paket program metode nodal tervalidasi lainnya (validated code), yang telah terbukti akurasinya dalam banyak kasus perhitungan neutronik reaktor PWR, seperti PARCS ${ }^{(10)}$ dan NESTLE ${ }^{(1)}$, maka Tabel 8 menunjukkan bahwa hasil perhitungan NODAL3 sangat memuaskan karena nilai $\Delta k_{\text {eff }}$ (\%)-nya berada dalam rentang hasil yang diperoleh dua paket program tersebut.

Tabel 7. Nilai $k_{\text {eff }}$ teras benchmark 3-D hasil perhitungan NODAL3

\begin{tabular}{|c|c|c|c|c|c|c|}
\hline \multirow[b]{2}{*}{$\begin{array}{c}\text { Teras 3-D } \\
\text { Benchmark }\end{array}$} & \multirow[b]{2}{*}{ Pitch, cm } & \multicolumn{3}{|c|}{ Program NODAL3 } & \multirow[b]{2}{*}{$k_{\text {eff }}$ acuan (5) } & \multirow[b]{2}{*}{$\begin{array}{r}\text { Perbedaan } \\
\left(\Delta k_{\text {eff }}(\%)\right)\end{array}$} \\
\hline & & $\begin{array}{l}\text { Node } \\
\text { radial }\end{array}$ & $\begin{array}{l}\text { Node } \\
\text { aksial } \\
\text { (aktif) }\end{array}$ & $k_{\text {eff }}$ & & \\
\hline \multirow{2}{*}{ IAEA-3D } & \multirow{2}{*}{20} & $1 \times 1$ & 17 & 1,02892 & \multirow{2}{*}{1,02904} & 0,012 \\
\hline & & $2 \times 2$ & 17 & 1,02900 & & 0,004 \\
\hline
\end{tabular}

Catatan : * $=$ nilai absolut

Tabel 8. Nilai $k_{\text {eff }}$ teras IAEA-3D hasil perhitungan beberapa program nodal

\begin{tabular}{|c|c|c|c|}
\hline Paket Program Nodal & $k_{\text {eff }}$ & \multirow{2}{*}{$k_{\text {eff }}$ acuan ${ }^{(5)}$} & $\begin{array}{c}\text { Perbedaan* } \\
\left(\Delta k_{\text {eff }}(\%)\right)\end{array}$ \\
\hline NODAL3 & 1,02900 & \multirow{2}{*}{1,02904} & 0,004 \\
\hline PARCS & 1,02910 & & 0,006 \\
\hline NESTLE & 1,02909 & & 0,005 \\
\hline
\end{tabular}

\section{Catatan : * $=$ nilai absolut}

Untuk menghitung $F P D_{\text {max }}$ teras IAEA-3D, tampak jelas bahwa pengaruh penambahan jumlah node ke arah radial di setiap $F A$, dari $1 \times 1$ menjadi $2 \times 2$, juga sangat berpengaruh dalam akurasi perhitungan. Hal ini terlihat dari perbedaan $\mathrm{FPD}_{\mathrm{Rmax}}$ hasil perhitungan NODAL3 dengan acuan menjadi berkurang dari $-0,011$ menjadi $-0,001$ atau akurasinya meningkat $91 \%$. Demikian juga dalam menentukan akurasi distribusi $F P D_{R}$, penambahan node tersebut menurunkan nilai RMS dari $7,1683 \times 10^{-3}$ menjadi $1,0919 \times 10^{-3}$, yang artinya distribusi $F D_{R}$ di setiap $F A$ yang dihitung paket program NODAL3 mendekati distribusi FPD $\mathrm{R}_{\mathrm{R}}$ acuan karena nilai RMS berkurang $84 \%$.

Tabel 9. Nilai FPD ${ }_{\max }$ dan RMS untuk teras benchmark 3-D

\begin{tabular}{|c|c|c|c|c|c|}
\hline \multirow{2}{*}{$\begin{array}{l}\text { Teras 3-D } \\
\text { Benchmark }\end{array}$} & \multicolumn{2}{|c|}{ Program NODAL3 } & \multirow{2}{*}{$\begin{array}{l}F P D_{\text {max }} \\
\text { acuan (5) }\end{array}$} & \multirow{2}{*}{$\begin{array}{l}\text { Perbedaan FPD } \text { max }_{\text {maL3) }} \\
\text { (Acuan - NODAL }\end{array}$} & \multirow{2}{*}{$\begin{array}{c}\text { RMS (root mean } \\
\text { square) }\end{array}$} \\
\hline & Node & $F P D_{\text {Rmax }}$ & & & \\
\hline \multirow{2}{*}{ IAEA-3D } & $1 \times 1$ & 1,443 & \multirow{2}{*}{1,432} & $-0,011$ & $7,1683 \times 10^{-3}$ \\
\hline & $2 \times 2$ & 1,433 & & $-0,001$ & $1,0919 \times 10^{-3}$ \\
\hline
\end{tabular}

Akurasi NODAL3 relatif lebih tinggi jika dibanding dengan program nodal PARCS dan NESTLE dalam perhitungan $\mathrm{FPD}_{R}($ Tabel 10$)$, karena memiliki perbedaan dengan acuan yang paling kecil yaitu $-0,001$. Demikian 
juga dengan nilai RMS FPD, hasil perhitungan paket program NODAL3 memberikan nilai yang paling kecil. Hal ini menunjukkan bahwa distribusi FPD hasil program NODAL3 adalah yang paling dekat dengan acuan dibanding program nodal PARCS dan NESTLE.

Tabel 10. Nilai FPD $\mathrm{Rmax}_{\text {man }}$ RMS teras IAEA-3D hasil perhitungan beberapa program nodal

\begin{tabular}{|c|c|c|c|c|}
\hline $\begin{array}{c}\text { Paket Program } \\
\text { Nodal }\end{array}$ & FPD $_{\text {Rmax }}$ & $\begin{array}{c}\text { FPD }_{\text {Rax }} \\
\text { acuan (5) }\end{array}$ & $\begin{array}{c}\text { Perbedaan FPD } \\
\text { (Acuan-Perhitungan) }\end{array}$ & $\begin{array}{c}\text { RMS (root mean } \\
\text { square) }\end{array}$ \\
\hline NODAL3 & 1,433 & \multirow{3}{*}{1,432} & $-0,001$ & $1,0919 \times 10^{-3}$ \\
\cline { 1 - 2 } \cline { 4 - 5 } \cline { 4 - 5 } & & 0,007 & $5,0203 \times 10^{-3}$ \\
\hline PARCS & 1,425 & 0,006 & $4,2088 \times 10^{-3}$ \\
\hline NESTLE & 1,426 & &
\end{tabular}

Dalam kasus 3-D, perhitungan faktor puncak daya ke arah aksial maksimun, $\mathrm{FPD}_{\mathrm{Amax}}$, sangat penting karena merupakan parameter keselamatan reaktor. Tabel 11 menunjukkan akurasi perhitungan NODAL3 untuk perhitungan $F P D_{A \max }$ dibanding acuan sebagai fungsi jumlah node ke arah radial. Seperti dibahas sebelumnya, dalam perhitungan $\mathrm{FPD}_{\text {Amax }}$, jumlah node ke arah aksial adalah $17(20 \mathrm{~cm} /$ node), dan jumlahnya tidak divariasi. Tampak jelas dari Tabel 11, bahwa nilai PPD $_{\text {Amax }}$ tidak bergantung pada perubahan jumlah node ke arah radial, karena selisihnya hanya 0,001 .

Hasil perhitungan NODAL3 relatif lebih dekat dengan acuan walaupun tidak signifikan jika dibandingkan dengan program nodal PARCS dan NESTLE, karena perbedaan dalam rentang 0,001 - 0,004. Hal ini menunjukkan bahwa perhitungan NODAL3 konsisten dengan hasil paket program nodal PARCS dan NESTLE yang sudah tervalidasi (validated code).

Tabel 11. Hasil perhitungan $\mathrm{FPD}_{\mathrm{Amax}}$ teras IAEA-3D hasil perhitungan beberapa program nodal

\begin{tabular}{|c|c|c|c|}
\hline Nama Program & FPD $_{\text {Amax }}$ & $\begin{array}{c}\text { FPD }_{\text {Amax }} \\
\text { acuan (5) }\end{array}$ & $\begin{array}{c}\text { Perbedaan FPD } \\
\text { Amax } \\
\text { (Acuan-Perhitungan) }\end{array}$ \\
\hline NODAL3 $(1 \times 1)$ & 1,557 & & 0,050 \\
\hline NODAL3 $(2 \times 2)$ & 1,556 & \multirow{2}{*}{1,607} & 0,051 \\
PARCS & 1,553 & & 0,054 \\
\hline NESTLE & 1,555 & & 0,052 \\
\hline
\end{tabular}

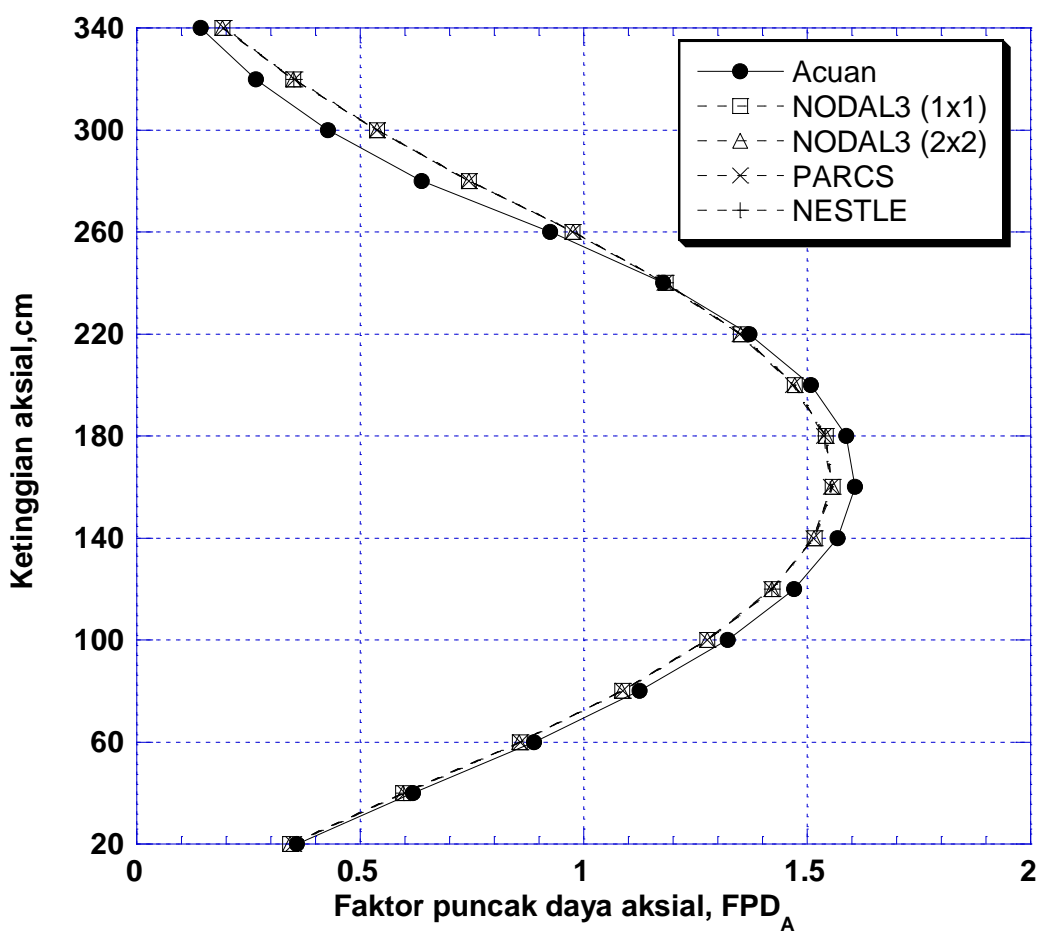

Gambar 8. Distribusi faktor puncak daya aksial ( $\left.\mathrm{FPD}_{\mathrm{ax}}\right)$ ke arah aksial teras IAEA-3D 
Hasil perhitungan distribusi faktor puncak daya ke arah aksial $\left(\mathrm{FPD}_{\mathrm{A}}\right)$ teras IAEA-3D ditunjukkan di dalam Gambar 8. Terlihat jelas bahwa distribusi $F P D_{A}$ hasil perhitungan NODAL memiliki profil yang sama dengan acuan. Perbedaan yang relatif besar terjadi disekitar posisi aksial $140 \mathrm{~cm}-180 \mathrm{~cm}$ dan $280 \mathrm{~cm}-320 \mathrm{~cm}$, masing-masing di tempat terjadinya $F P D_{A m a x}$ dan di daerah sekitar masuknya batang kendali $(260 \mathrm{~cm}-340 \mathrm{~cm})$. Disekitar posisi 140 $\mathrm{cm}-180 \mathrm{~cm}$, perbedaan maksimum hasil perhitungan dan acuan sebesar $3,3 \%$, sedangkan di posisi $280 \mathrm{~cm}-320$ $\mathrm{cm}$, perbedaannya $4,1 \%$. Gambar 8 juga menunjukkan hasil perhitungan distribusi $\mathrm{FPD}_{\mathrm{A}}$ dengan paket program NODAL3 memiliki konsistensi hasil dengan program nodal PARCS dan NESTLE untuk seluruh posisi aktif teras ke arah aksial dengan nilai yang relatif sama.

Ternyata hasil perhitungan $k_{\text {eff }}$ dan FPD baik ke arah radial dan aksial diantara tiga paket program NODAL3, PARCS dan NESTEL memiliki kesamaan yang tinggi seperti terlihat di Tabel 7-11 dan Gambar 8,. Setelah dilakukan kajian terhadap beberapa pustaka ${ }^{(3,12)}$, hal ini disebabkan kerena ketiga paket program ini menggunakan metode yang sama dalam penanganan diskritisasi ruang, yaitu coarse mesh finite difference (CMFD).

\section{KESIMPULAN}

Akurasi paket program NODAL3 dalam menghitung parameter neutronik teras benchmark PWR, baik kasus 2-D dan 3-D, menunjukkan hasil yang sangat memuaskan baik dibandingkan dengan acuan dan validated code, seperti PARCS dan NESTLE. Dalam penelitian ini, dibuktikan bahwa penggunaan jumlah node $2 \times 2$ per perangkat bahan bakar ke arah radial menjadi pilihan untuk mendapatkan akurasi perhitungan yang tinggi. Perbedaan maksimum dengan acuan untuk nilai $k_{\text {eff }}$ adalah $0,006 \%(\Delta k)$. Sedangkan untuk FPD maksimum ke arah radial dan aksial masing-masing memiliki selisih maksimum dengan acuan adalah $-0,006$ dan 0,051 . Karena kasus teras benchmark yang dipilih adalah untuk jenis reaktor PWR, maka paket program NODAL3 siap untuk diaplikasikan dalam analisis neutronik teras PWR yang riil.

\section{UCAPAN TERIMAKASIH}

Penulis mengucapkan terimakasih kepada Kementerian Riset dan Teknologi Republik Indonesia yang telah memberikan dana penelitian ini melalui proyek penelitian PI-PKPP 2011 dalam judul kegiatan "Evaluasi dan Verifikasi Parameter Keselamatan Operasi PLTN PWR 1000 dari Aspek Neutronik.".

\section{DAFTAR PUSTAKA}

1. P. REUSS, Neutron Physics, EDP Sciences-Les Ulis Cedex France (2008)

2. ANONYM, NODAL3: A Nodal Neutron Diffusion Code, version 2," User's Guide (2010)

3. T.M. SEMBIRING dan S PINEM, "Validasi Program NODAL3 pada Teras Benchmark PWR NEACRP," Prosiding Seminar Nasional ke-14 Teknologi Keselamatan PLTN dan Fasilitas Nuklir, PTRKN-BATAN, (2009) $172-178$

4. E.Z. MULLER and E.J. WEISS, Ann. Nucl. Energy, 18, (1991) 535-544

5. R.R. LEE et.al., Argonne Code Centre: Benchmark Problem Book, Report No.: ANL-7416, Supp. 2, ID.11-A2, Argonne National Laboratory (US), (1977) 277-466

6. N. GUESSOUS and M. AKHMOUCH, Ann. Nucl. Energy, 29, (2002) 1765-1778.

7. N. VOSOUGHI, A.A.SALEHI and M. SHAHRIARI, Ann. Nucl. Energy , 31, (2004) 231-253

8. T.Y. HAN, H.G. JOO, H.C. LEE and C.H. KIM, Ann. Nucl. Energy, 35, (2008) 1975-1985

9. R.D.S. YADAV and H.P. GUPTA, Ann. Nucl. Energy, 38, (2011) 2086-2095

10. https://engineering.purdue.edu/PARCS/Code/TestSuite/CalculationMode/StandAloneMode/Eigenvalue/ IAEA3DPWR/Outputiaea3d.out (2012)

11. I. ARIANI dan D. KASTANYA, "Evaluation of the IAEA-3D PWR Benchmark Problem Using NESTLE Code," Prosiding Lokakarya Komputasi Dalam Sains dan Teknologi Nuklir ke-15, PPIN-BATAN, (2005) 20-25

12. T. DOWNAR, Y. XU, V. SEKER and N. HUDSON, Theory Manual for the PARCS Kinetics Core Simulator Module, U.S.NRC-Rockville, Maryland, (2010) 12-16 